\title{
INFLUENCE OF ORGANIC MANURES AND GIRDLING DATES ON HEAY METAL ACCUMULATIONS OF APPLE FRUIT AFTER TWO SEASONS OF APPLICATION
}

\author{
AZAD A. MAYI \\ Dept. of Horticulture, College of Agriculture, University of Duhok, Kurdistan Region - Iraq
}

(Received: November 13, 2018; Accepted for Publication: April 28, 2019)

\begin{abstract}
This investigation was carried out during season of 2014-2015 on five years old apple tree (Malus dumestica Borkh) cv. Xank grown in the orchard at Gavarky, Duhok governorate, Kurdistan region, Iraq. To study the effect of two girdling date before full bloom and after fruit set, compost application at levels $(0,3$ and 5kg.tre $\left.{ }^{-1}\right)$ and sheep manure application at three levels $\left(0,4\right.$ and $\left.6 \mathrm{~kg}^{-t r e e^{-1}}\right)$, on heavy metals accumulation of apple fruits after two years of application. According to obtained results, it noticed that girdling (date 2) was best time for girdling, gave the higher level of $\mathrm{Cd}, \mathrm{Cu}, \mathrm{pb},\left(0.082,1.619\right.$ and $0.311 \mathrm{mg}^{-\mathrm{L}^{-}}$ ${ }^{1}$ ) respectively, and Compost specially at $(5) \mathrm{kg} \cdot \mathrm{tree}^{-1}$ has significantly increased fruit heavy metal content Cd, $\mathrm{Cu}, \mathrm{pb}, \mathrm{Zn}\left(0.073,1.963,0.352\right.$ and $\left.10.861 \mathrm{mg}^{-\mathrm{L}^{-1}}\right)$. Sheep manure specially at $(6) \mathrm{kg}^{-}$.tree ${ }^{-1}$ significantly increased the fruit nutrients content $\mathrm{Cd}, \mathrm{pb}, \mathrm{Cu}, \mathrm{Zn}\left(0.069,1.674,0332\right.$ and $\left.13.344 \mathrm{mg}^{-1} \mathrm{~L}^{-1}\right)$, while, the interactions between girdling, compost and sheep manure significantly affected most of the studied parameters and the more effective treatment interactions was girdling $\left(\mathrm{D} 2+5 \mathrm{~kg}^{-}\right.$Tree $^{-1}$ of compost plus 6kg.Tree ${ }^{-1}$ of sheep) manure significantly increased $\mathrm{Cd}, \mathrm{pb}, \mathrm{Cu},\left(0.119,2.843\right.$ and $\left.0.401 \mathrm{mg}^{-\mathrm{L}^{-1}}\right)$ respectively.
\end{abstract}

KEYWORD: Girdling, Sheep manure, Compost, heavy metal, Apple fruit

\section{INTRODUCTION}

$\mathbf{T}$ The Apple (Malus domestica Borkh) is perennial tree belonged to Rosaceae family, its popular to be consumed due to their convenience and durability. It has arisen in the Caucasus region of southeastern Europe (Watkins et al., 2013). There are more than 2000 varieties of apple grow in temperate climate zones and in a wide range of soil types (Azad, 2007).

The compost has an important role in the agriculture sector because it contain a high amount of elements necessary for plant growth and soil improvement, the use of compost as a fertilizer for plant in Kurdistan and Iraq has a large space and this is backward in the field of agriculture when we compare with the progressive countries (Azad and Nawzad, 2015) (Azad and Hasan, 2016). Recently researchers have started to give attention positive effect of organic manure application more than of chemical fertilization for environment and on human beings healthy as sheep manure and compost (Janick, 2007. (Pinamonti, et al., 1997) studied the effect of cattle manure; SB compost from (Sewage sludge and poplar Barks) and MSW
(Municipal Solid Waste) compost in 14 different of Malus domestica orchards. The results clearly shown that using compost (MSW) about six-year period causes increasing the concentration of $\mathrm{Zn}$, $\mathrm{Pb}$ and $\mathrm{Cd}$ in the soil and also the $\mathrm{Pb}$ and $\mathrm{Cd}$ then these metals will transform to the fruits Pinamonti et al., (2007). (AL-Kahtani and Soliman, 2012) investigate the effect of different mixtures of organic fertilizers on olive trees composted agriculture waste (1 Date palm: 1 olives: 1 maize) $+10 \%$ sheep manure resulted in decreasing heavy metals concentration $(\mathrm{Pb}, \mathrm{Ni}, \mathrm{Co}$ and $\mathrm{Cd})$.

Thus, I was encouraged to use the compost as a first study in Kurdistan and Iraq in order to encourage our farmer to use the compost as a plant fertilizer. The risks and problems posed by heavy metals in fertilizers and other soil inputs have increasingly drawn the attention of farmers, environmental organizations, consumers, and public policymakers. This study examines a wide spectrum of soil amendments and fertilizers used in organic agriculture, including biosolids, major nutrient fertilizers, industrial wastes, composts, liming materials and micronutrient sources with a focus on inputs used in organic agricultural production in Iraq (Azad and Nawzad 2015). 
Girdling is usually carried out by cutting through the phloem and removing a strip of tissue from the bark of tree. When no strip of tissue is removed, the process is seems to as scoring. The main function of girdling is to reduce the transfer of carbohydrates to lower parts of the tree and to the roots. In this way, carbohydrates were accumulated above the girdling area (Davie et al., 1995). According to (Minh, et al., 2012) the girdling of Wax apple that done before flowering about three weeks, lead to reduce bud drop, and fruit drop. They found that girdling lead to enhance fruit parameters.

This investigation aimed to study the effect of compost, sheep manure, girdling and their interactions on some heavy metals concentration in apple fruit after two seasons applications. The risk of heavy metal concentration in apple fruits by compost or sheep manure fertilization program, and relationship on human health, since there are little or no studies in Kurdistan about the role of organic fertilization in yield and quality of apple fruits.

\section{MATERIALS AND METHODS}

This study was carried out on private orchard of six years old of local cv.Xank apple trees, located in Gavarky, center of Duhok city during season 2014-2015. To investigate the effect of girdling date, sheep manure and compost after two years of application on heavy metal accumulation in fruits of cv. Xank. Girdling was done by removing the bark of three main branches of each tree carefully about $5-6 \mathrm{~mm}$ in two times date (D1) before flowering on 9/3/2014 and date (D2) after fruit set on 19/4/2014 by knife. The application of compost and sheep manure was done in January $26^{\text {th }} 2014$, (Table 2 and 3 ) by a working hole around the tree under the projection of brunches at three levels $\left(0,3\right.$, and $5 \mathrm{~kg} \cdot$ tree $\left.^{-1}\right)$, $\left(0,4\right.$, and $6 \mathrm{~kg} \cdot$ tree $\left.^{-1}\right)$, respectively. The compost that was used in this experiment consisted from resides waste of Duhok city, produced in Kowashi factory of compost fertilizer. The experiment was consisted of 18 treatments with three replications ; with individual tree for each experimental unit, using Randomize Complete Block Design (RCBD) as factorial experiment (Al-Rawi and Khalaf-Alla, 2000). Moreover, the data were analyzed statistically by using (SAS, 2000). Soil, compost and sheep manure analysis was carried out at Faculty of Agricultural Research Center in Duhok (Table 1, 3), Eggersmann Company (Table 2).

Table (1): Some physical and chemical properties of the orchard soil

\begin{tabular}{|c|c|c|c|}
\hline Properties & Results & Properties & Results \\
\hline Moisture continent \% & 2.57 & Zn mg.kg-1 & 0.058 \\
\hline $\mathrm{pH}$ & 7.64 & Fe $\mathrm{mg} \cdot \mathrm{kg}^{-1}$ & 0.195 \\
\hline E C ds.m ${ }^{-1}$ & 0.37 & $\mathrm{~Pb} \mathrm{mg} \cdot \mathrm{kg}^{-1}$ & 0.354 \\
\hline CEC cmol.kg ${ }^{-1}$ & 25.18 & $\mathrm{Cd} \mathrm{mg} \cdot \mathrm{kg}^{-1}$ & 0.053 \\
\hline Clay\% & 32.95 & & \\
\hline Silt \% & 42.02 & & \\
\hline Sand \% & 24.97 & & \\
\hline Texture \% & Silty Clay & & \\
\hline
\end{tabular}

The soil analysis carried out in the soil laboratory, soil and water department, College of Agriculture, University of Duhok.

Table (2): Some parameters of compost produced in factory of Duhok city tested by Eggersmann

\begin{tabular}{llll}
\hline Parameters & Lab test results & $\begin{array}{l}\text { Company (2014). } \\
\text { compost standard }\end{array}$ & $\begin{array}{l}\text { Recommendation for Kurdistan standard } \\
\text { in year }\end{array}$ \\
\hline Dry matter & $87.4 \%$ & & \\
\hline Moisture content & $12.6 \%$ & \\
\hline Organic matter & $54.4 \%$ & \\
\hline Salt content KCl/I & $8.77 \mathrm{~g}$ &
\end{tabular}




\begin{tabular}{|c|c|c|c|c|c|}
\hline pH-value & 7.3 & & & & \\
\hline Total N & $1.54 \%$ & & & & \\
\hline Total $\mathbf{P}\left(\mathrm{P}_{2} \mathrm{O}_{2}\right)$ & $0.54 \%$ & & & & \\
\hline Total $\mathrm{P}\left(\mathrm{K}_{2} \mathrm{O}\right)$ & $0.80 \%$ & & & & \\
\hline Heavy metals (mg.kg ${ }^{-1}$ ) & & & 2014 & 2018 & 2022 \\
\hline Cadmium (Cd) & 3.74 & 1.5 & 4.0 & 2.5 & 1.5 \\
\hline Lead (Pb) & 252 & 120 & 160 & 140 & 120 \\
\hline Zinc (Zn) & 562 & 600 & 600 & 600 & 600 \\
\hline
\end{tabular}

Table (3): Some parameters of sheep manure tested in College of Agriculture Duhok University at (2014).

\begin{tabular}{ll}
\hline Parameters & Sheep manure analysis \\
\hline Total $\mathrm{N} \%$ & 6.83 \\
\hline $\mathrm{K} \%$ & 1.03 \\
\hline $\mathrm{P} \%$ & 5.36 \\
\hline Fe mg. $\mathrm{kg}^{-1}$ & 0.354 \\
\hline Zn mg.kg & 0.031 \\
\hline Heavy metals & $\left(\mathrm{mg} \cdot \mathrm{kg}^{-1}\right)$ \\
\hline $\mathrm{Pb}$ & 0.646 \\
\hline $\mathrm{Cd}$ & 0.035 \\
\hline
\end{tabular}

\section{MEASUREMENTS:}

Heavy metals nutrient concentration of fruit:

After taking fruit dry weight, $0.5 \mathrm{gm}$ of dried samples were taken for digestion using a mixture of concentrated $\mathrm{H}_{2} \mathrm{SO}_{4}$ with $\mathrm{H}_{2} \mathrm{O}_{2}(10 \mathrm{ml})$ and (5ml) respectively (Stylianidis et al., 2004). Then heavy metals were determined by using atomic absorption (Mehmet, 2010).

1. Cadmium (mg.kg $\left.{ }^{-1}\right)$ 2.Copper $\left(\mathrm{mg}^{\left.-\mathrm{kg}^{-1}\right)} 3\right.$.

Lead (mg.kg $\left.{ }^{-1}\right)$ 4. Zinc (mg.kg $\left.{ }^{-1}\right)$

\section{RESULTS AND DISCUSSIONS}

\section{1-Cadmium concentrations of fruit (mg.kg $\left.{ }^{-1}\right)$}

The table (4) indicates that the concentration of cadmium in fruit that in girdle (D2) $\left(0.083 \mathrm{mg} . \mathrm{kg}^{-}\right.$ $\left.{ }^{1}\right)$ was more than of girdle (D1) $\left(0.022 \mathrm{mg} \cdot \mathrm{kg}^{-1}\right)$. It was noticed that the sheep manure application to the Xank apple trees has visible effect in the concentration of cadmium in fruits especially at (6 kg.tree $\left.{ }^{-1}\right)$ gave the highest value $\left(0.069 \mathrm{mg} \cdot \mathrm{kg}^{-1}\right)$ compared with control $\left(0.034 \mathrm{mg}^{-\mathrm{kg}^{-1}}\right)$. The compost application at $\left(5 \mathrm{~kg} \cdot \mathrm{tree}^{-1}\right)$ resulted in higher cadmium concentrations in fruit that was $\left(0.073 \mathrm{mg} \cdot \mathrm{kg}^{-1}\right)$ compared with control $\left(0.03 \mathrm{mg} . \mathrm{kg}^{-}\right.$ $\left.{ }^{1}\right)$. The results in table (4) display that the interactions among girdling (D2) + 6kg.tree ${ }^{-1}$ sheep manure $+5 \mathrm{~kg} \cdot$ tree $^{-1}$ compost give the highest (Cd) conc. in fruit $\left(0.119 \mathrm{mg} \cdot \mathrm{kg}^{-1}\right)$. Nevertheless, the lowest value obtained from control of three factors which was $\left(0.008 \mathrm{mg} \cdot \mathrm{kg}^{-1}\right)$.

2- Copper concentrations of fruit ( ${\left.\mathrm{mg} . \mathrm{kg}^{-1}\right)}^{-1}$

It is obvious in table (5) that girdling (D2) has significant increase in the conc. of copper $\left(1.619 \mathrm{mg} \cdot \mathrm{kg}^{-1}\right)$ in fruit than $\left(1.144 \mathrm{mg} \cdot \mathrm{kg}^{-1}\right)$ those on trees of girdling (D1). The results fairly display that the soil application of sheep manure has a significant increase in the copper concentration in fruits especially at $6 \mathrm{~kg} \cdot \mathrm{tree}^{-1}$ that was $\left(1.674 \mathrm{mg} \cdot \mathrm{kg}^{-1}\right)$. Moreover, the lowest value obtained with control (1.028mg.kg $\left.{ }^{-1}\right)$. Regarding the triple interactions among girdling date (D2) + 6 kg.tree ${ }^{-1}$ sheep manure +5 kg.tree ${ }^{-1}$ compost resulted in higher copper conc. $\left(2.843 \mathrm{mg} \cdot \mathrm{kg}^{-1}\right)$ in fruits as compared with all other treatment combinations.

\section{3- Lead concentrations of fruit ( $\left.\mathrm{mg}^{\mathrm{kg}}{ }^{-1}\right)$}

Table (6) shows that the lead concentration in fruit is higher $\left(0.311 \mathrm{mg} \cdot \mathrm{kg}^{-1}\right)$ with girdling (D2) than (0. 293 $\left.\mathrm{mg} \mathrm{kg}^{-1}\right)$ from girdling (D1). Application of sheep manure at both levels had significant increase in the concentration of lead in fruit $\left(0.332 \mathrm{mg} \cdot \mathrm{kg}^{-1}\right)$ compared with $\left(0.242 \mathrm{mg} \cdot \mathrm{kg}^{-}\right.$ $\left.{ }^{1}\right)$ from control. The compost application at $5 \mathrm{~kg} \cdot$ tree $^{-1}$ caused increase in the concentration of lead in fruit $\left(0.352 \mathrm{mg} \cdot \mathrm{kg}^{-1}\right)$ compared with control

$\left(0.240 \mathrm{mg} \cdot \mathrm{kg}^{-1}\right)$. 
Table (4): Effect of girdling date, sheep manure, compost and their interactions on fruit cadmium (mg.kg$\left.{ }^{1}\right)$ concentrations of apple tree cv. Xank at season 2015.

\begin{tabular}{|c|c|c|c|c|c|c|}
\hline \multirow[t]{2}{*}{ Girdling date } & \multirow{2}{*}{$\begin{array}{l}\text { Sheep Manure } \\
\left(\text { kg.tree }^{-1}\right)\end{array}$} & \multicolumn{3}{|c|}{ Compost (kg.tree $^{-1}$ ) } & \multirow[t]{2}{*}{ GD * Sh } & \multirow[t]{2}{*}{ Girdling } \\
\hline & & $\overline{0}$ & 3 & 5 & & \\
\hline \multirow[t]{3}{*}{ D1 } & 0 & $0.008 \mathrm{i}$ & $0.012 \mathrm{f}-\mathrm{i}$ & $0.017 \mathrm{fg}$ & $0.012 \mathrm{e}$ & $0.022 \mathrm{~b}$ \\
\hline & 4 & $0.012 \mathrm{~h}-\mathrm{g}$ & $0.015 \mathrm{f}-\mathrm{h}$ & $0.016 \mathrm{fg}$ & $0.014 \mathrm{e}$ & \\
\hline & 6 & $0.011 \mathrm{hi}$ & $0.017 f$ & $0.092 \mathrm{~d}$ & $0.040 \mathrm{~d}$ & \\
\hline \multirow[t]{3}{*}{ D 2} & 0 & $0.008 \mathrm{i}$ & $0.070 \mathrm{e}$ & $0.092 \mathrm{~d}$ & $0.057 \mathrm{c}$ & $0.082 \mathrm{a}$ \\
\hline & 4 & $0.068 \mathrm{e}$ & $0.099 \mathrm{c}$ & $0.105 \mathrm{~b}$ & $0.091 \mathrm{~b}$ & \\
\hline & 6 & $0.073 \mathrm{e}$ & $0.104 \mathrm{bc}$ & $0.119 \mathrm{a}$ & $0.099 \mathrm{a}$ & \\
\hline \multicolumn{2}{|c|}{ Compost } & $0.03 \mathrm{c}$ & $0.053 \mathrm{~b}$ & $0.073 \mathrm{a}$ & \multicolumn{2}{|c|}{ Sheep manure } \\
\hline \multirow[t]{2}{*}{$D * C$} & $\overline{\text { D1 }}$ & $0.008 \mathrm{f}$ & $0.015 \mathrm{e}$ & $0.041 \mathrm{~d}$ & & \\
\hline & D2 & $0.052 \mathrm{c}$ & $0.091 \mathrm{~b}$ & $0.105 \mathrm{a}$ & & \\
\hline \multirow[t]{3}{*}{ Sh ${ }^{*} \mathrm{C}$} & 0 & $0.008 \mathrm{e}$ & $0.041 \mathrm{~d}$ & $0.054 \mathrm{c}$ & \multicolumn{2}{|c|}{$0.034 \mathrm{c}$} \\
\hline & 4 & $0.040 \mathrm{~d}$ & $0.057 \mathrm{bc}$ & $0.061 \mathrm{~b}$ & \multicolumn{2}{|c|}{$0.053 \mathrm{~b}$} \\
\hline & 6 & $0.042 \mathrm{~d}$ & $0.061 \mathrm{~b}$ & $0.106 \mathrm{a}$ & \multicolumn{2}{|c|}{$0.069 \mathrm{a}$} \\
\hline
\end{tabular}

The same letters in means of each interactions was not significantly different from each other according to Duncan's multiple ranges test at $5 \%$ level.

Table (5): Effect of girdling date, sheep manure, compost and their interactions on fruit copper ( $\left.\mathrm{mg}^{\mathrm{kg}} \mathrm{kg}^{-1}\right)$ concentrations of apple tree cv. Xank at season 2015.

\begin{tabular}{|c|c|c|c|c|c|c|}
\hline \multirow[t]{2}{*}{ Girdling date } & \multirow{2}{*}{ 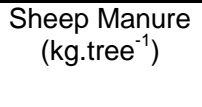 } & \multicolumn{3}{|c|}{ Compost (kg.tree $\left.{ }^{-1}\right)$} & \multirow[t]{2}{*}{ GD * Sh } & \multirow[t]{2}{*}{ Girdling } \\
\hline & & 0 & 3 & 5 & & \\
\hline \multirow[t]{3}{*}{ D1 } & 0 & $0.143 \mathrm{i}$ & $1.037 \mathrm{~g}$ & $1.143 \mathrm{ef}$ & $0.774 \mathrm{f}$ & $1.144 \mathrm{~b}$ \\
\hline & 4 & $0.880 \mathrm{~h}$ & 1.140 ef & $1.670 \mathrm{~d}$ & $1.230 \mathrm{e}$ & \\
\hline & 6 & $1.083 \mathrm{fg}$ & $1.160 \mathrm{e}$ & $2.037 \mathrm{~b}$ & $1.427 \mathrm{c}$ & \\
\hline \multirow[t]{3}{*}{ D 2} & 0 & $0.143 \mathrm{i}$ & $1.663 \mathrm{~d}$ & $2.040 \mathrm{~b}$ & $1.282 \mathrm{~d}$ & $1.619 \mathrm{a}$ \\
\hline & 4 & $1.020 \mathrm{~g}$ & $1.893 \mathrm{c}$ & $2.047 \mathrm{~b}$ & $1.653 \mathrm{~b}$ & \\
\hline & 6 & $1.023 \mathrm{~g}$ & $1.897 \mathrm{c}$ & $2.843 \mathrm{a}$ & $1.921 \mathrm{a}$ & \\
\hline \multicolumn{2}{|c|}{ Compost } & $0.715 \mathrm{c}$ & $1.465 \mathrm{~b}$ & $1.963 \mathrm{a}$ & \multicolumn{2}{|c|}{ Sheep manure } \\
\hline \multirow[t]{2}{*}{ GD * C } & $\overline{D 1}$ & $0.702 \mathrm{e}$ & $1.112 \mathrm{~d}$ & $1.617 \mathrm{c}$ & & \\
\hline & D 2 & $0.729 \mathrm{f}$ & $1.818 \mathrm{~b}$ & $2.310 \mathrm{a}$ & & \\
\hline \multirow[t]{3}{*}{ Sh ${ }^{*} \mathrm{C}$} & 0 & $0.143 \mathrm{~h}$ & $1.350 \mathrm{e}$ & $1.592 \mathrm{c}$ & \multicolumn{2}{|c|}{$1.028 \mathrm{c}$} \\
\hline & 4 & $0.950 \mathrm{~g}$ & $1.517 \mathrm{~d}$ & $1.858 \mathrm{~b}$ & \multicolumn{2}{|c|}{$1.442 \mathrm{~b}$} \\
\hline & 6 & $1.053 \mathrm{f}$ & $1.528 \mathrm{~d}$ & $2.440 \mathrm{a}$ & \multicolumn{2}{|c|}{$1.674 \mathrm{a}$} \\
\hline
\end{tabular}

The same letters in means of each interactions was not significantly different from each other according to Duncan's multiple ranges test at $5 \%$ level.

The result of interactions treatment of girdling (D2) $+6 \mathrm{~kg} \cdot$ tree $^{-1}$ sheep manure $+5 \mathrm{~kg} \cdot \mathrm{tree}^{-1}$ compost gave great significant differences in the concentration of lead in fruit the value documented $\left(0.401 \mathrm{mg} \cdot \mathrm{kg}^{-1}\right)$, as compared with all other treatment combinations. 
Table (6): Effect of girdling date, sheep manure, compost and their interactions on fruit lead (mg. $\left.\mathrm{kg}^{-1}\right)$ concentrations of apple tree cv. Xank at season 2015.

\begin{tabular}{|c|c|c|c|c|c|c|}
\hline \multirow[t]{2}{*}{ Girdling date } & \multirow{2}{*}{$\begin{array}{l}\text { Sheep Manure } \\
\left(\mathrm{kg}^{-} \cdot \mathrm{tree}^{-1}\right)\end{array}$} & \multicolumn{3}{|c|}{${\text { Compost }\left(\mathrm{kg} \cdot \text { tree }^{-1}\right)}$} & \multirow[t]{2}{*}{$\mathrm{GD} * \mathrm{Sh}$} & \multirow[t]{2}{*}{ Girdling } \\
\hline & & 0 & 3 & 5 & & \\
\hline \multirow[t]{3}{*}{ D1 } & 0 & $0.106 \mathrm{j}$ & $0.282 \mathrm{~h}$ & $0.305 \mathrm{~d}$ & $0.231 \mathrm{e}$ & $0.293 \mathrm{~b}$ \\
\hline & 4 & $0.302 \mathrm{~g}$ & $0.332 \mathrm{e}$ & $0.361 \mathrm{~b}$ & $0.332 \mathrm{~b}$ & \\
\hline & 6 & $0.304 \mathrm{~g}$ & $0.304 \mathrm{~g}$ & $0.341 \mathrm{~d}$ & $0.316 \mathrm{c}$ & \\
\hline \multirow[t]{3}{*}{ D 2} & 0 & $0.106 \mathrm{i}$ & $0.301 \mathrm{~g}$ & $0.351 \mathrm{c}$ & $0.253 d$ & $0.311 \mathrm{a}$ \\
\hline & 4 & $0.313 \mathrm{f}$ & $0.334 \mathrm{e}$ & $0.352 \mathrm{c}$ & $0.333 \mathrm{~b}$ & \\
\hline & 6 & $0.311 \mathrm{f}$ & $0.330 \mathrm{e}$ & $0.401 \mathrm{a}$ & $0.347 \mathrm{a}$ & \\
\hline \multicolumn{2}{|c|}{ Compost } & $0.240 \mathrm{c}$ & $0.314 \mathrm{~b}$ & $0.352 \mathrm{a}$ & \multirow{3}{*}{\multicolumn{2}{|c|}{ Sheep manure }} \\
\hline \multirow[t]{2}{*}{$\mathrm{GD}{ }^{*} \mathrm{C}$} & D 1 & $0.237 f$ & $0.306 \mathrm{~d}$ & $0.336 \mathrm{~b}$ & & \\
\hline & D 2 & $0.243 \mathrm{e}$ & $0.322 \mathrm{c}$ & $0.368 \mathrm{a}$ & & \\
\hline \multirow[t]{3}{*}{ Sh *C } & 0 & $0.106 \mathrm{~h}$ & $0.292 \mathrm{~g}$ & $0.328 \mathrm{~d}$ & \multicolumn{2}{|c|}{$0.242 \mathrm{~b}$} \\
\hline & 4 & $0.307 f$ & $0.333 \mathrm{c}$ & $0.357 \mathrm{~b}$ & \multicolumn{2}{|c|}{$0.332 \mathrm{a}$} \\
\hline & 6 & $0.308 \mathrm{f}$ & $0.317 \mathrm{e}$ & $0.371 \mathrm{a}$ & \multicolumn{2}{|c|}{$0.332 \mathrm{a}$} \\
\hline
\end{tabular}

The same letters in means of each interactions was not significantly different from each other according to Duncan's multiple ranges test at $5 \%$ level.

\section{4-Zinc concentration of fruit ( $\left.\mathrm{mg}^{\mathrm{kg}}{ }^{-1}\right)$}

The table (7) shows that the zinc concentration in fruits $\left(9.922 \mathrm{mg} \cdot \mathrm{kg}^{-1}\right)$ of girdle tree (D1) was more than (9.193mg. $\mathrm{kg}^{-1}$ ) from girdling (D2). Obviously, the sheep manure application has significant influence in increasing the concentration of zinc in fruit at $\left(6 \mathrm{~kg} \cdot \mathrm{tree}^{-1}\right)$ resulted in higher significant increase in the zinc

Table (7): Effect of girdling date, sheep manure, compost and their interactions on fruit zinc $\left(\mathrm{mg} . \mathrm{kg}^{-1}\right)$ concentrations of apple tree cv. Xank at season 2015.

\begin{tabular}{|c|c|c|c|c|c|c|}
\hline \multirow[t]{2}{*}{ Girdling date } & \multirow{2}{*}{$\begin{array}{l}\text { Sheep Manure } \\
\left(\mathrm{kg}^{\left.- \text {tree }^{-1}\right)}\right.\end{array}$} & \multicolumn{3}{|c|}{ Compost (kg.tree ${ }^{-1}$ ) } & \multirow[t]{2}{*}{ GD * Sh } & \multirow[t]{2}{*}{ Girdling } \\
\hline & & 0 & 3 & 5 & & \\
\hline \multirow[t]{3}{*}{ D1 } & 0 & $3.267 j$ & $5.400 i$ & $5.267 \mathrm{i}$ & $4.644 \mathrm{f}$ & $9.922 \mathrm{a}$ \\
\hline & 4 & $7.533 \mathrm{gh}$ & $11.833 \mathrm{c}$ & $11.067 \mathrm{~cd}$ & $10.144 \mathrm{c}$ & \\
\hline & 6 & $16.000 \mathrm{a}$ & $14.933 \mathrm{ab}$ & $14.000 \mathrm{~b}$ & $14.978 \mathrm{a}$ & \\
\hline \multirow[t]{3}{*}{ D 2} & 0 & $3.267 \mathrm{j}$ & $10.200 \mathrm{de}$ & $11.200 \mathrm{~cd}$ & $8.2222 \mathrm{~d}$ & $9.193 b$ \\
\hline & 4 & $6.533 \mathrm{hi}$ & $7.200 \mathrm{gh}$ & 9.200 ef & $7.644 \mathrm{e}$ & \\
\hline & 6 & $8.533 \mathrm{fg}$ & $12.167 \mathrm{c}$ & $14.433 \mathrm{~b}$ & $11.711 \mathrm{~b}$ & \\
\hline \multicolumn{2}{|c|}{ Compost } & $7.917 \mathrm{c}$ & $10.289 \mathrm{~b}$ & $10.861 \mathrm{a}$ & \multirow{3}{*}{\multicolumn{2}{|c|}{ Sheep manure }} \\
\hline \multirow[t]{2}{*}{$G D * C$} & D 1 & $8.933 \mathrm{~d}$ & $10.722 \mathrm{~b}$ & $10.111 \mathrm{bc}$ & & \\
\hline & D 2 & $6.111 \mathrm{e}$ & 9.856 & $11.611 \mathrm{a}$ & & \\
\hline \multirow[t]{3}{*}{$S h{ }^{*} \mathrm{C}$} & 0 & $3.267 f$ & $7.800 \mathrm{de}$ & $8.233 \mathrm{~d}$ & \multicolumn{2}{|c|}{$6.433 \mathrm{c}$} \\
\hline & 4 & $7.033 \mathrm{e}$ & $9.517 \mathrm{c}$ & $10.133 \mathrm{c}$ & \multicolumn{2}{|c|}{$8.894 \mathrm{~b}$} \\
\hline & 6 & $12.267 \mathrm{~b}$ & $13.550 \mathrm{a}$ & $14.217 \mathrm{a}$ & \multicolumn{2}{|c|}{$13.344 \mathrm{a}$} \\
\hline
\end{tabular}

concentration in fruit manure (13.344mg. $\mathrm{kg}^{-1}$ ) compared with control $\left(6.433 \mathrm{mg} \cdot \mathrm{kg}^{-1}\right)$. The data in table (7) illustrates that the interactions effect of the three studied factors the interaction treatment of girdling (D1) $+6 \mathrm{~kg} \cdot$ tree $^{-1}$ sheep manure + $0 \mathrm{~kg}$. tree $^{-1}$ compost gave the highest value that was $\left(16.000 \mathrm{mg} \cdot \mathrm{kg}^{-1}\right)$, as compared with all other treatment

combinations. The same letters in means of each interactions was not significantly different from each other according to Duncan's multiple ranges test at $5 \%$ level. 


\section{DISCUSSION}

The effect of compost and sheep manure on the leaf heavy metal accumulations may be due to the improvement of soil physical, biological properties and chemical properties resulting more release of nutrient elements available which absorbed by plant root and its effect on the physiological process, such as the photosynthesis activity as well as the utilization of carbohydrates, in addition to water use efficiency, also adequate nutrient quantities of nitrogen, phosphorus, and potassium, which increase both rate of leaf expansion as well as cell division which subsequently leads to larger individual leaves and higher photosynthesis activities (Abd El-Wahab, 2011; Azad and Nawzad,2015). May be attributed to a higher nutritional uptake mainly by greater expansion of root system due to increased supply of photosynthetic productions in the leaves, attributed to presence of plant growth regulators (Ge'rard et.al., 2000 and Arancon et.al., 2004 ).

\section{REFERENCES}

- Abd El-Wahab, M. A. (2011). Reducing the Amount of Mineral Nitrogen Fertilizers for Red Globe Grapevines by Using Different Sources of Organic Fertilizers. J. Amer. Sci. 7(8): 810-819.

- Al-Kahtani, S. H., and S. S. Soliman (2012). Effects of organic manures on yield, fruit quality, nutrients and heavy metals content of Barhy date palm cultivar. African Journal of Biotechnology, 11(65), 12818-12824.

- Al-Rawi, A. A. and A. Khalaf-Alla (2000). Analysis of Experimental Agriculture Design. Dar AlKutub for Printing and Publishing. Mosul University. Iraq. (In Arabic).

- Arancon N. Q., C. A. Edwards, P. Bierman b, C. Welch, J. D. Metzger (2004). Influences of vermicomposts on field strawberries: 1. Effects on growth and yields, Bioresource Technology 93 145-153

- Azad A. M. and N. J. Ibrahim ( 2015). Effect of Cultivars, Compost, Humic Acid and Their Interactionss on Leave Heavy Metal Accumulation of Sweet Cherry (Prunus avium
L.). JUD. Vol. 18, No.1 (Agri. and Vet. Sciences), Pp 76-86.

- Azad A. M. (2007). Effect of foliar spray with iron and GA3 on the vegetative growth, nutrient contents, yield and some storage characteristics of Apple fruits cvs. 'Barwari' and 'Starking'

- Azad A. M. and Hasen S. Nabi (2016) .Influence of Organic Manures and Girdling Dates on Flowering and Yields of Apple Fruit after Two Years Application, $2^{\text {ed }}$ conference of Agri.college of UoD .Iraq. Kurdistan region

- Davie, S.J., P.J.C. Stassen, M. van der Walt and B. Snijder (1995). Girdling avocado trees for improved production. South African Avocado Growers' Association Yearbook. 18:51-53

- Ge'rard, E., G. Echevarria, T. Sterckman, and J. L. Morel (2000). Cadmiun availability to three plant species varying in cadmiun accumulation pattern. J. of Environmental Quality 29, $1117-$ 1123.

- Janick, J. (2007). The origins of horticultural technology and science. Acta Horticulturae, (759), 41-60.

- Mehmet A.B. (2010). The Effects of Sewage Sludge Applications on The Yield, Growth, Nutrition and Heavy Metal Accumulation In Apple Trees Growing In Dry Conditions Turk J Agric For 27 :285-292.

- Minh, T., N., and R. Y. Chung (2012). Effect of SGirdling on fruit growth and fruit quality of wax apple. World Academy of Science, Engineering and Technology. Vol: (6), 12-26

- Pinamonti, F., G. Stringari, F. Gasperi, and G. Zorzi (2007). The use of compost: its effects on heavy metal levels in soil and plants, Resources, Conservation and Recycling 21. 129-143.

- SAS Institute, Inc (2000). The SAS system. Relase 6.12. Cary, NC

- Stylianidis D. K., T. E. Soteropoulos, M. A. Koukourikou, D. G. Voyiatzis and I. N. Thrios (2004). The effect of growth regulators on fruit shape and inorganic nutrient concentration in leaves and fruit of 'Red Delicious' apples. J. Bio.Res.1:75-80.

- Watkins, C. B., E. Kupferman, and D. A. Rosenberger (2013). Apple. Washington State University 
يوخته

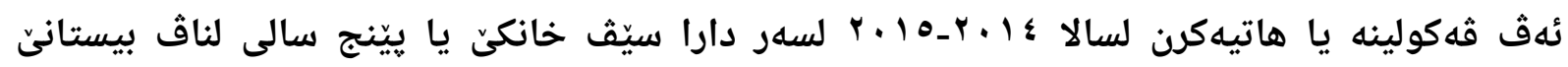

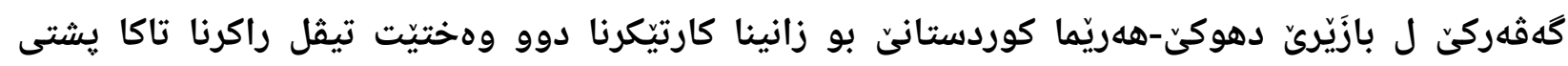

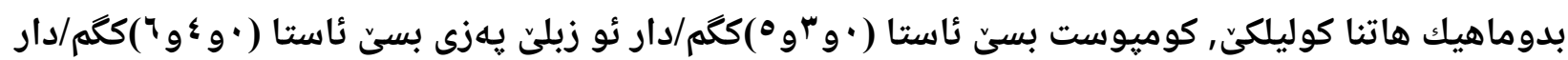

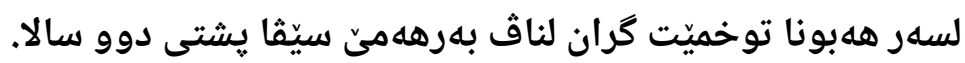

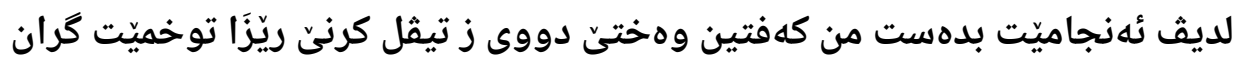

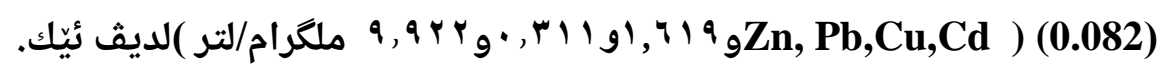

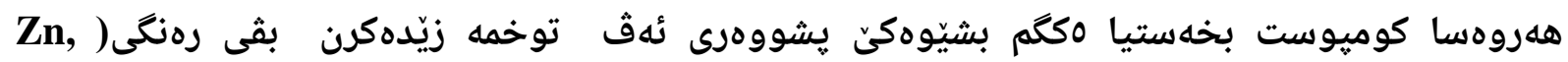

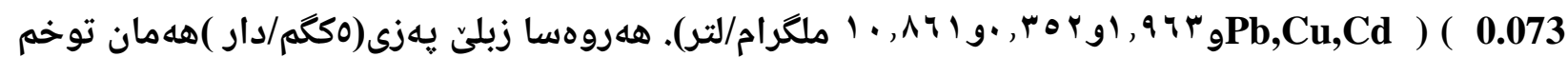
زيّدهكرن بثى رهنگى (Zn,Pb,Cu,Cd)

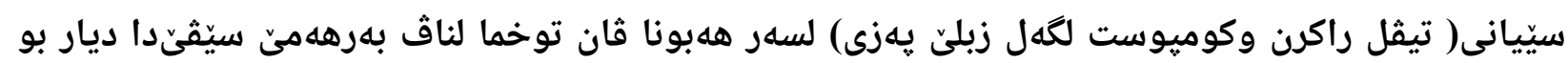

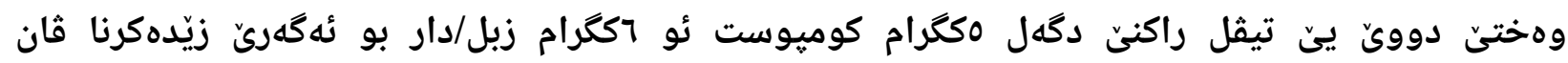

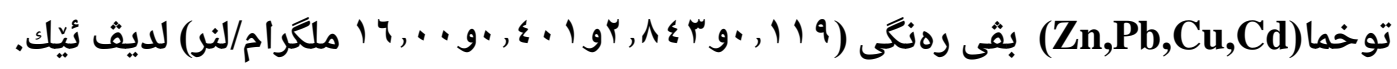

